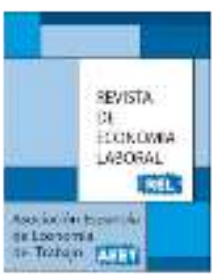

\title{
WAGES IN AND OUT OF THE PUBLIC SECTOR: NEW INSIGHTS FOR SIX SELECTED EUROPEAN COUNTRIES ${ }^{1}$
}

\author{
Paola Naddeo ${ }^{2}$ \\ Italian National Institute of Statistics
}

Accepted June 2016

\begin{abstract}
This paper aims to draw a comparative picture of some basic features of the public sector labour market in six European economies (France, Germany, Italy, Spain, Sweden, the United Kingdom). Relying upon the Eurostat Structure of Earnings Survey (EU-SES), the Oaxaca-Blinder decomposition was applied to various subsets of the workforce. Issues of comparability are emphasised, by posing civil servants against their appropriate counterparts, i.e. employees from large private firms, by considering jobs and professional figures within the same sectors (Education, Human health, and Local utilities), and by considering workers characterised by similar levels of education. We consider not only hourly earnings but also monthly earnings. We find a wage premium in the public sector in the UK and Spain and to some extent in Italy (only for hourly earnings). Less educated employees working in the public sector fare generally better in terms of the premium compared to their more educated colleagues.
\end{abstract}

Keywords: Public-Private Wage Premium, Wage Inequality, Wage Decomposition, Gender Pay Gap

JEL Classification: J31, J45, J71

\footnotetext{
${ }^{1}$ This paper summarized the main results of the thesis for SESS (Socio-Economic and Statistical Studies) P.h.D., Sapienza Università di Roma, Italy. We are very thankful to Prof. Sergio Destefanis for having supported our project, to Prof. Rosa Nonell for having given us the opportunity to visit the Department of Economic Policy and World Economic Structure of the Universitat de Barcelona and to all the participants of the SESS P.h.D. network for the useful comments. We would like to express our sincere gratitude to Prof. Raul Ramos for his observations and precious comments on the methodology adopted. We wish to acknowledge the support from Dr. Stefania Cardinaleschi, coordinator of the Structure of Earnings Survey at ISTAT, for the useful information on the Italian part of the Survey. Finally, we would like to thank two anonymous referees for their very useful comments and suggestions. However, we will use some of their suggestions to refine the research in future works.

${ }^{2}$ ISTAT (Italian National Institute of Statistics), Via Cesare Balbo, 16 - 00184 Roma; Tel. +39 0646734383 naddeo@ istat.it; paola.naddeo@fastwebnet.it
}

C Revista de Economía Laboral 


\section{Resumen}

El presente trabajo ofrece una foto comparativa de algunas las características básicas del mercado de trabajo en relación con el sector público para seis economías europeas (Francia, Alemania, Italia, España, Suecia y el Reino Unido). En base a los datos de Eurostat Structure of Earnings Survey (EU-SES), se aplica la descomposición de Oaxaca - Blinder a diversos subgrupos de la población activa. Se matizan los problemas de comparabilidad existentes entre los funcionarios públicos y su contraparte: los empleados de las grandes empresas privadas; teniendo solamente en cuenta los puestos de trabajo y las figuras profesionales existentes dentro del sector de actividad común (Educación, Salud humana y los servicios públicos locales) para aquellos trabajadores con una educación similar. Adicionalmente, se considera no solo los salario hora sino también mensuales. Los resultados indican que existe una prima salarial en el sector público para el caso de Reino Unido y España y levemente en el caso de Italia (solo para el salario hora). En general, los trabajadores del sector público menos educados se encuentran mejor en términos de la prima percibida que sus colegas más educados.

Palabras claves: Prima salarial pública o privada, Desigualdad salarial, Descomposición salarial, Gap Salarial por Género.

Clasificación JEL: J31, J45, J71 


\section{Introduction}

Despite the difficulties in comparing heterogeneous situations we can presume the existence of relevant differences between to be employed in the public sector or to be employed in the private sector (as a whole). The public sector labour market has many peculiar characteristics that differentiate it from the standard private sector labour market, such as criteria adopted to select, recruit and promote workers, to determine wage levels, as well as wage profiles, career advancement and industrial relations. Nevertheless, relatively little attention has been paid to analyse its functioning. This is surprising considering the importance of the public sector for the total employment: in 2013, $15 \%$ of the European men and $37 \%$ of women were employed in the public sector. In Norway, Denmark and Sweden more than $50 \%$ of female workers were civil servants.

One reason for the higher female presence in the public sector could be that in many European countries, especially Mediterranean ones, working in this sector allows for a better reconciliation between work and family duties. More generally, the public sector has been traditionally depicted as a form of protected area, with stable employment and relatively high wages despite low productivity. Once hired, public employees enjoy life-time contracts in which seniority plays a major role; they cannot be discharged, except for misconduct, and the statutory terms apply regardless of whether the worker is employed at the national, regional or local authority level (Lucifora and Meurs, 2006). Since the 1990's, policies aiming to bridge the gap between the dynamics of the labour markets in the public and private sectors have been progressively introduced. In the last years the process has been accelerated due to the financial crisis and the consequent need to reduce high public debts (Vaughan-Whitehead, 2013; Glassner and Watt, 2010). The existence of a wage premium in the public sector, when civil servants enjoy higher wages compared to workers in the private sector, could be an easy justification for cutting real and (sometimes also nominal) wages in the public sector.

In this paper we use the Eurostat Structure of Earnings Survey (EU-SES) to investigate the differences in wage determination across the public and the private sector. We are mainly interested in the measurement of the so-called wage premium, but, unlike most of the existing literature, we focus mainly on the comparison between public 
employers and large private enterprises (hereafter LPEs: firms with more than 250 employees).

The reason for focusing mainly on LPEs is that the rules governing the public sector labour market are more homogeneous than those of the private sector. Public employees have substantially the same rights and wages independently of working in small or large establishments, differently from the private sector. Trade-unions strength and human resource management tend to be more similar in the public and private sector when the latter is represented by LPEs. The public sector could be deemed as a country's largest employer; hence the correct comparison should be between public sector and LPEs.

There are other issues of cross-sector comparability. Following the existing literature, we shall allow systematically for gender-based differences and compare workers endowed with similar levels of educational attainment. We also consider jobs and professional figures within the same sectors (NACE's P (Education), Q (Human health and social work activities), and Local utilities). For jobs existing only in the public sector (public administration and defence; compulsory social security) there is no sense to compare earnings with the private sector. Thus, only jobs and professional figures within similar sectors have been considered.

Moreover we don't restrict our analysis only to hourly earnings, but we believe that a correct comparison between the public and the private sector should also be based on monthly earnings. Some people, especially women, who choose to work in the public sector, may do so because it allows for better reconciliation between work and family life. In other words, they may prefer lower earnings in exchange for shorter and more flexible working schedules. Considering only hourly earnings could be misleading when the wage premium is associated with shorter work hours, especially when people are interested in the purchasing power of their total earnings ${ }^{3}$. This is not a novelty in the empirical literature, as monthly earnings have already been used in several works (see e.g. Depalo et al. 20134).

\footnotetext{
3 The hourly earnings are calculated by dividing the employees' gross monthly earnings by the hours they usually work each month; in some cases (Italy and Sweden) we have calculated them due to the absence of the data on hourly earnings in the database. If the data on working time were not correctly reported, we record a premium that could derive from the difficulty of measuring the working time.

4 The authors also look at what happens to the wage premium when the comparison is limited only to the LPEs.
} 
The structure of the paper is the following: after a literature review, the third section describes in some detail the analytical framework; in the fourth section the EU-SES database is presented, while the fifth section includes the main empirical results; the last section contains some concluding remarks.

\section{A Literature survey}

Despite the importance of public employment for the total economy, relatively few studies have tried to understand in detail the functioning of the public sector labour market. A critical review of the literature leads to its classification into three main groups:

a) "macro" literature focused mainly on pathologies of the public sector labour market (overmanning, vote trading, etc.) and on its possible crowding out effect on private employment;

b) literature on the public wage premium based on micro-data;

c) less numerous literature that tried to analyse some specific characteristics of public employees.

In the first group there are authors considering the choice to employ workers in the public sector by contrasting it with competitive private labour markets. They stress how the objective of public decisionmakers may be different from the achievement of socially optimal outcomes. The activities of politicians and bureaucrats, linked to clientelism and vote trading, could produce overmanning in the public sector, and then perverse redistribution of wealth, unjustified welfare state provision, crowding out of private employment, etc. (see, for example, Alesina et al., 1999; Robinson and Verdier, 2013; Algan et al., 2002; Forni and Giordano, 2003; Gomes, 2010 and 2015).

In the second group there is a wide empirical literature that has shown the existence of a wage differential in favour of public employees, although it provides no theoretical explanation for it. The problems faced by most of these contributions are how to deal with heterogeneity (employees differ for many characteristics: gender, age, skills, preference, etc.) and the choices to work in different sectors (selection bias). The numerous contributions include Depalo and Giordano (2011), Giordano et al. (2011), Dell'Aringa et al. (2007), Bargain and Melly (2007), Disney (2007), Lucifora and Meurs (2006), Ghinetti and Lucifora (2013) and Hospido and Moral-Benito (2014). Several previous works 
use EU-SES data to estimate the wage premium: inter alia, De Castro et al. (2014), Ramos et al. (2014).

The main results of De Castro et al. (2014) are that in Europe on average the public sector wage premium with respect to the whole private sector is equal to 0.105 log points, and about two thirds are explained by different characteristics endowments (although in several countries such as Sweden and France there is a negative wage premium). Contrary to other empirical works there is not a clear evidence of a higher positive premium for women, although in most cases women in the EU Member Sates before 2004 tend to enjoy higher earnings in the public sector than their male counterparts. On average, the premium is higher for older workers, for lower levels of education and for lower job positions.

Ramos et al. (2014) limit their analysis to Spain; for the analysis they recourse not only to Oaxaca-Blinder decomposition model but also to Ñopo approach (see the next paragraph). They find a significant wage differential in Spain in favour of public sector workers that, in line with the previous studies, can be explained largely by their different endowments of observed characteristics, while the size of the resulting pay premium is appreciably higher in the case of women. The evidence obtained also suggests that the establishment characteristics make a greater contribution to the differential than individual or job characteristics.

Finally there is a third group, composed of few studies, that tries to investigate the peculiar characteristics of public employees, including civil servants' motivations, such as altruism and mission oriented (see for example Francois, 2000; Besley and Ghatak, 2005, Buurman et al., 2012), the different degree of aversion to risk of public and private employees (Bellante and Link, 1981; Bonin et al., 2007; Pfeifer, 2011), the great attractiveness for public employees of high job security (Cappellari, 2002) and low wage mobility (Budria, 2010; Postel-Vinay and Turon, 2007). For example, Bellante and Link (1981) suggest that if the sorting process in the public and private sector depends on the degree of risk aversion, then those individuals with a high degree of aversion to risk will be more likely than others to seek employment in the public sector. It means that if the wage is similar there could be a queue to enter in the public sector. Bonin et al. (2007) and Pfeifer (2011), using German Socioeconomic Panel data, find that the probability of being employed in the public sector is higher for risk adverse workers. 
These three approaches seem to have different conflicting points. First and foremost, if the wage in the public sector acts as a sort of welfare support provision, with competitive labour and product markets, we should observe higher remuneration in the private sector, but this is not what seems to happen according to the wage premium literature. In relationship to this point little attention has been paid to the role of trade unions, which are however of paramount importance in the public sectors of the European economies. More generally, the empirical analyses represented by the literature on wage premium have many problems in terms of incorporating several characteristics of public employees highlighted in the third group of the literature. For example, as noticed by Disney (2007) and Ramos et al. (2014), some jobs can exist only in the public sector; for these jobs the comparison with the private sector makes no sense.

Moreover, despite the high number of empirical studies devoted to analyse the magnitude of the wage premium, few studies have tried to explain the reasons for it. Recently Campos et al. (2016) have tried to explain the cross-country heterogeneity in the wage premium. Their analysis confirms the hypothesis of the existence of non-competitive forces that drive the determination of wages in the public sector. They find that more than half of the cross-sectional variation in public pay gaps can be accounted for by the size and the composition of the labour force in the public sector. The observed wage gaps have been significantly higher in countries where the percentage of public employees was lower, a composition of the public workforce tilted towards goods that are provided exclusively by the public sector and that are less opened to international competition. The recent downward trend of the gap can be explained by the widespread process of fiscal consolidation rather than by structural factors. The improvements in the quality of governments can be associated with decreases in the public pay gap.

\section{The empirical framework}

This paper performs an empirical analysis of the wage premium in the public sector and tries to resolve some of the problems highlighted in the literature in regard to this. The most important problem to be faced is heterogeneity. Workers and employers are different between public and private sector but also within sectors, 
although the differences are higher in the private sector. Workers differ in terms of their innate abilities, their acquired skills and their preferences (including risk aversion). One obvious way to deal with heterogeneity is to divide the sample in many (more homogenous) subsamples. The problem for the empirical analysis is that each subsample may be too small to grant statistical representativeness to the results.

Here we follow most of the empirical literature by considering a decomposition of the public-private earnings gap derived mainly along the lines of the Oaxaca-Blinder specification ${ }^{5}$. This approach allows estimation of the part of the observed gap that can be explained by observed differences between workers (i.e. where different outcomes are explained by group differences in endowments and structural characteristics), and a residual, unexplained, part that has been variously labelled as the "premium", the residual advantage to be employed in a certain job, the discriminatory gap, and so on. Clearly, this unexplained part could depend on unobserved characteristics of workers and jobs that we are not able to take into consideration.

To deal with the problems of heterogeneity and omitted variables, the literature has often suggested solutions based on the quantile regression ${ }^{6}$; another solution is the so-called Nopo matching procedure, that considers the differences in the supports of the distributions of observable characteristics, i.e. the fact that some jobs exist only in the public sector and civil servants generally do not perform jobs performed in the private sector. The Nopo nonparametric approach does not require the estimation of earnings equations and divides the gap into four additive elements: two of these are analogous to the elements of the Oaxaca-Blinder decomposition (but computed only over the common support), while the other two account for differences in the supports (Ñopo, 2008). It has been observed that it could incur in a problem of high dimensionality?

${ }^{5}$ A very wide survey of the alternative decomposition methods could be found in Fortin et al. (2010).

${ }^{6}$ Another possible solution is the Fortin et al. (2010) decomposition. See Ramos et al. (2014) for a recent application.

${ }^{7}$ Another way (largely used in the study of gender pay gap) to deal with the problems of unobserved variables is the Heckman correction (Heckman, 1979). The underlying idea of the Heckman correction is that employees belonging to each subset whose earnings are compared differ in a number of measurable variables. The observed wage is the result of the interaction between employers' choice and employees' decisions. In most of the literature, the employees' decision is captured by the observation of the selection processes, while the employers' choice could be captured by the determination of wages, 
In this paper, we follow a solution more explicitly connected with some of the civil servants' characteristics highlighted in the literature. We first present the results of a typical Oaxaca-Blinder decomposition for the whole economy, but we privilege the comparison of civil servants with private employees from LPEs. Also, we systematically allow for gender-based differences. Then we show the effects of the two different exercises of disaggregation. The first exercise consists in dividing workers by highest education level attained and in repeating the Oaxaca-Blinder decomposition separately for each group. The second exercise is to carry out the Oaxaca-Blinder decomposition for sectors characterised by a significant presence of both public and private workers, basically NACE's P (Education), Q (Human health and social work activities) ${ }^{8}$ and local utilities (hereafter LU's) ${ }^{9}$. As future work, we intend to compare our results with those obtained using the Nopo matching procedure.

Six countries are considered for the analysis: the four largest Euro-area countries (Italy, France, Germany and Spain) plus the United Kingdom, the largest country outside Euro-area, and Sweden, a relatively large economy well-known for the peculiar characteristics of its welfare state and the high incidence of public sector on female employment.

Traditionally there are two different specifications of the Oaxaca-Blinder decomposition: the first one is the so-called "three-fold" model $^{10}$, the second one a "two-fold" model 11 . In this paper we limit our

conditional on employees' choice. In order to avoid an identification problem we need to have some variables that influence the choice of the sector by workers but not wage determination per se. In general, these variables are represented by socio-demographic characteristics. Unfortunately, as already observed by Ramos et al. (2014), the SES database only deals with matched employer-employee data, and does not contain this type of variables.

${ }^{8}$ Instead of $\mathrm{Q}$ sector we have to consider the following sector together X86 (Human health activities), X87 (Residential care activities), X88 (Social work activities without accommodation) and X75 (Veterinary activities); the reason is that for most countries the data are presented at this level of aggregation.

9 For France, Spain, Sweden and the UK Local utilities include X35 (Electricity, gas, steam and air conditioning supply), X36 (Water collection, treatment and supply), X49 (Land transport and transport via pipelines), X50 (Water transport), X51 (Air transport) and X52 (Warehousing and support activities for transportation); for Germany, in addition to the previous sectors: X37 (Sewerage), X38 (Waste collection, treatment and disposal activities: materials recovery) and X39 (Remediation activities and other waste management services); for Italy only X35, X36, X49 and X52.

10 This model was originally proposed by Winsborough and Dickinson (1971), as quoted, for example, by Daymont and Andrisani (1984). 
analysis to the (more intuitive) second model and we implement it using the Oaxaca module worked out by Jann (2008) for Stata, which allows for heteroskedasticity-robust standard errors.

The wage equations, for private and public sector labour markets, are the traditional Mincer equations:

$$
\ln W_{i}=\beta_{i} X_{i}+\epsilon_{i}
$$

where:

$$
\begin{aligned}
& W=\text { wages } \\
& X=\text { a vector containing the characteristics of workers and a } \\
& \text { constant term } \\
& \beta=\text { a vector containing the slope parameters and the intercept } \\
& i \text { stands for public (A) or private (B) sector }
\end{aligned}
$$

The difference between public and private average wage is:

$$
R=E\left(\ln W_{A}\right)-E\left(\ln W_{B}\right)=E\left(X_{A}\right)^{\prime} \beta_{A}-E\left(X_{B}\right)^{\prime} \beta_{B}
$$

let $\beta^{*}$ be a non-discriminatory coefficient vector (that can be used to determine the contribution of the differences in the parameters); equation (2) can be expressed as:

$R=\left\{E\left(X_{A}\right)-E\left(X_{B}\right)\right\}^{\prime} \beta^{*}+\left\{E\left(X_{A}\right)^{\prime}\left(\beta_{A}-\beta^{*}\right)+E\left(X_{B}\right)^{\prime}\left(\beta^{*}-\beta_{B}\right)\right\}=Q+U$

where:

$Q=\left\{E\left(X_{A}\right)-E\left(X_{B}\right)\right\}^{\prime} \beta^{*}$

is the outcome differential explained by group differences in the variables, and

$U=E\left(X_{A}\right)^{\prime}\left(\beta_{A}-\beta^{*}\right)+E\left(X_{B}\right)^{\prime}\left(\beta^{*}-\beta_{B}\right)$

is the unexplained part.

The unexplained part is usually attributed to discrimination or premium (the first term could be considered the discrimination in favour of group A, the second against group B), but obviously could also reflect the effects of unobserved variables.

${ }^{11}$ See, for example, Fortin et al. (2010). 
In this paper we provide also an estimation of the contribution of the different predictors to the explained and unexplained parts of the public-private wage gap. Equation (4) can be expressed as:

$$
\hat{Q}=\left(\bar{X}_{A}-\bar{X}_{B}\right)^{\prime \widehat{\beta}_{A}}=\left(\bar{X}_{1 A}-\bar{X}_{1 B}\right) \hat{\beta}_{1 A}+\left(\bar{X}_{2 A}-\bar{X}_{2 B}\right) \hat{\beta}_{2 A}+\ldots
$$

where $\bar{X}_{1}, \bar{X}_{2}, \ldots$ are the means of the single characteristics and $\hat{\beta}_{1}, \hat{\beta}_{2}$, ... are the associated coefficients.

Similarly, equation (5) can be expressed as:

$$
\widehat{U}=\bar{X}_{B}^{\prime}\left(\hat{\beta}_{A}-\hat{\beta}_{B}\right)=\bar{X}_{1 B}^{\prime}\left(\hat{\beta}_{1 A}-\hat{\beta}_{1 B}\right)+\bar{X}_{2 B}^{\prime}\left(\hat{\beta}_{2 A}-\hat{\beta}_{2 B}\right)+\ldots
$$

It has been noted that when we recourse to dummy variables the result of the decomposition of the unexplained part depends on the choice of the base category, so we need to transform the dummy variables as proposed by Gardeazabal and Ugidos (2004) and Yun (2005). The main problem with this transformation is that the economic interpretation of the result is not always clear (Fortin et al. 2010).

\section{The data}

The dataset employed in the paper is the Eurostat Structure of Earning Survey (EU-SES). We mainly rely on the most recent wave of this dataset referring to the year 2010. These data have already been utilised in order to analyse earning differences between public and private sectors by Ramos et al. (2014) for a single country (Spain) and by de Castro et al. (2013) for a broad analysis of the whole European Union. Here we will compare a limited number of countries with a deeper analytical focus than the one adopted by de Castro et al. (2013).

As often happens, the choice of a particular dataset has its pros and cons. The most important disadvantages of using the SES data are the inclusion of information only on employed workers and the absence of any information on work histories. However, there are many important advantages of using the SES data for the kind of analysis developed in this paper.

SES provides, for each country, harmonised information on a much larger number of employees than other sources and this allow a more correct comparison between countries. The data concern the level of remuneration, the individual characteristics of employees (sex, age, occupation, job tenure, etc.) and of their employers (economic activity, 
size and location), for all sectors of the economic activity, except NACE classification A (Agriculture, forestry and fishing), $\mathrm{T}$ (Activities of households as employers; undifferentiated goods - and services producing activities of households for own use) and $U$ (Activities of extra-territorial organisations and bodies). The SES generally does not cover micro-enterprises. Indeed, as indicated by Eurostat, "the inclusion of enterprises with fewer than 10 employees ... is optional".

For our purposes it is important to note that SES provides direct information on the proprietary form (public or private) of the firm in which the employee works. When dealing with other cross-country databases, such as EU-SILC, proprietary form is not directly provided by the questionnaire and must be obtained making some restrictive hypotheses (often inferring it from the NACE classification). In other words, by using the SES we overcome a very important source of uncertainty linked to considering (typically) as civil servants all the workers employed in particular sectors. At this juncture we must however point out that the inclusion of employers belonging to sector $\mathrm{O}$ (Public administration and defence; compulsory social security) of NACE classification is optional ${ }^{12}$. If a country, in our sample Italy, opts for not reporting the data for sector $\mathrm{O}$ there is an underrepresentation of the number of public workers. This should not be a problem when there are no private firms in sector $\mathrm{O}$; in other words this could be a case falling into Nopo (2008) critics of Oaxaca-Blinder decomposition, which we overcome by careful consideration of sectors (as well as firm size).

As observed by Eurostat (2010) SES data are "collected from tailored questionnaires, existing surveys, administrative sources or a combination of such sources, which provide the equivalent information". This careful validation activity ascertains that we are dealing with more reliable data than many other databases.

Moreover, the present analysis excludes young workers (below 20 years) and workers for which there is ambiguity about the size or the proprietary form (public or private) of their establishments. The econometric analysis, where we consider separately monthly and hourly

\footnotetext{
12 In Germany there is a distinction between public service employees and civil servants; workers in sector $\mathrm{O}$ fall into the category of civil servants. Moreover we have to remember that in Germany, as in many other countries, the results for sector $\mathrm{O}$ have been obtained not from a survey, but from model-based estimates. As observed by Eurostat: "The geographical comparability of the results of this section with other EU States and also between German regions is limited by the estimation procedures".
} 
earnings, shall also exclude part-timers. This allows a better comparison of the results obtained for the two types of earnings.

All the data presented in this paper are weighted for the grossing-up factor for employees indicated in the database ${ }^{13}$.

\section{The main results}

\subsection{The descriptive statistics}

In 2010, the countries with the greater share of public employees were Sweden, the UK and France (respectively 41.9\%, 31.7\% and $31.3 \%)$. Spain (18.2\%) is the country with the lowest relative number of employees in the public sector. The Italian and German data $(24.4 \%$ and 19.3\%) are ambiguous for the abovementioned considerations on lack of information about the sector $\mathrm{O}$ of the NACE classification for Italy and the distinction between public employees and civil servants in Germany (Figure 1). The quotas are higher for females than males: in Sweden, more than one woman out of two is employed in the public sector. Particularly high is also the quota of civil servants for women in the UK (more than 42\%) and France (about 39\%). Moreover, the incidence of public employees increases with age up to more than $70 \%$ in Sweden for females aged more than sixty years.

The rising quota of public employees on total employees by age, especially for female segment, could be a signal of the greater possibility to conciliate work with family responsibilities. For females working in the public sector the increasing family duties do not imply that they have to give up work, which is often the case in the private sector. In addition, firing old and "obsolete" workers in the public sector is more difficult than in the private sector.

\footnotetext{
13 According to Eurostat Structure of Earnings Survey 2010, Eurostat's arrangements for implementing the Council Regulation 530/1999, the Commission Regulations $1916 / 2000$ and 1738/2005, the grossing-up factor for employees is calculated as follows: (Number of employees in the population) / (Number of employees in the sample). This choice is coherent with the Eurostat indication: "Eurostat will apply [this] variable ... to the variables on microdata records for the employees to obtain population estimates of the total number of employees and their aggregate earnings (broken down by sex, age, FT/PT, etc.). The grossed up number of employees will be used for weighting purposes, including the calculation of European averages. Likewise, the grossed up number of employees will be used as the denominator for the calculation of employees' average earnings (hourly, monthly and annual), average paid hours, holidays, etc.".
} 
Figure 1. Quota of public employees by gender and age class. (percentage values)

Females

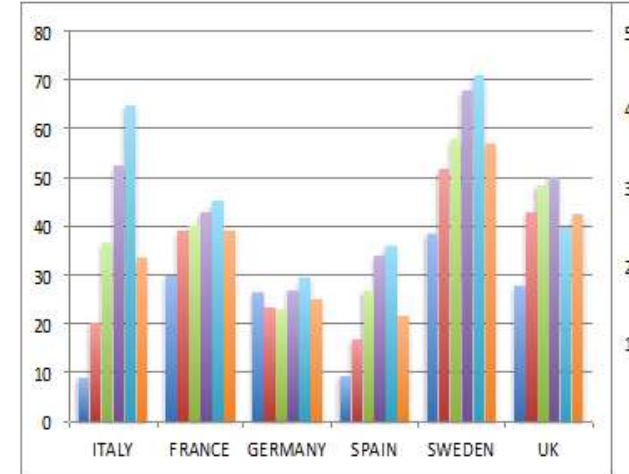

Males

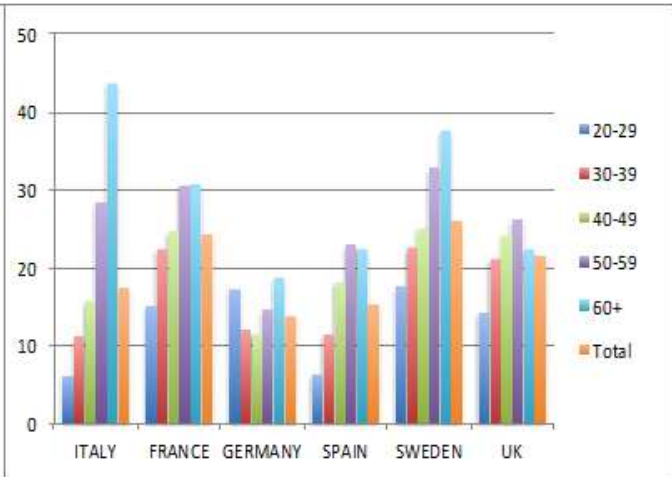

Source: Own elaboration on the Structure of Earning Survey, EUROSTAT, 2010

As is well known, part-time is a prevalently female phenomenon. This is true in all countries and for all types of enterprises, but the share of full-time workers varies considerably between countries. Public sector resorts less to part-time in Italy, Spain and France, which is not true in Germany, Sweden and the UK. In Germany the quota of female full-timers in the public sector is only of $38 \%$, in Italy it is more than $90 \%$.

Very huge differences are recorded for the education level, measured as "Highest successfully completed level of education and training"14. In all countries public employees have a higher level of education for both females and males compared to their counterparts in the LPEs (Figure 2). Generally, females in public sector possess higher level of education than males, which is not always the case in the LPEs. Sweden is the country in which public employees record the highest incidence of High level of education attained, on the contrary Italy is the country with the lowest incidence.

14 In this paper, instead of the classic Isced division we consider the following aggregation: Low (level of education attained): level 1 (Pre-primary education and primary education) and 2 (Lower secondary education); Medium: level 3 (Upper secondary and Post-secondary non tertiary education) and 4 (Tertiary education with occupation orientation - first stage); High: level 5 (Tertiary education with academic orientation - first stage) and 6 (Tertiary education - second stage). This is for two reason: to facilitate the comparison and the interpretation of data (few people get the ISCED level 1, 4 and 6) and because, unfortunately, Germany does not provide all the items for the classification of this variable, but only an aggregation of them. 


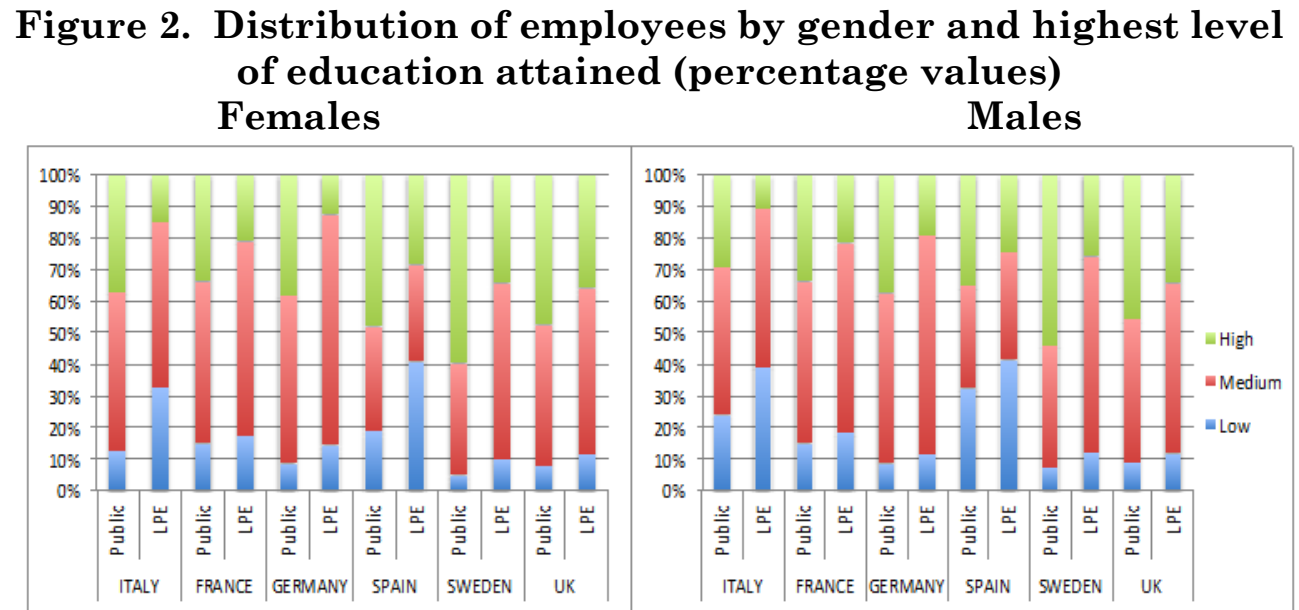

Source: Own elaboration on the Structure of Earning Survey, EUROSTAT, 2010

The most important difference between workers in the public sector and in the LPEs seems to be the job tenure, measured by SES through the "length of service in enterprise" (in years). In Italy, the average length of service in the public sector is over 16 years, in the LPEs it is about 11 years. In France and Germany the average data for public sector is about 14 years, whereas the data for LPEs are similar to Italy. In Spain the average length of tenure in the public sector is 13.4 years and it is much lower for LPEs. Finally, also in Sweden and the UK, civil servants record higher length of service than their colleagues in the private sector, although at lower levels than in the other countries considered ${ }^{15}$.

Job tenure obviously increases with age; this happens in all countries, with the partial exception of public males in the UK and female employees in LPEs in Spain and Italy. Job tenure is higher in the public sector than in LPEs for all age groups in all countries. Moreover, a positive and significant gap in favour of public sector is also always present for all levels of education and for all types of occupations in all countries.

As regards the comparison of wage levels, in Figure 3 we present the ratio between hourly earnings in the whole private sector or in the LPEs and in the public sector; the ratio lower than 100 indicates the presence of a wage gap in favour of public employees. There is no public

15 The gap is obviously still higher when we compare public sector with the whole private sector instead LPEs. 
wage gap in Sweden, both for females and males and both for LPEs and the whole private sector, and, for LPEs, also in France and Germany. So, the wage premium exists in Spain, Italy, the UK and partly France and Germany (private sector as a whole). The public wage premium is higher for females.

There are some differences when we consider the monthly earnings instead of hourly earnings: in Italy and Spain the public wage gap is sensible lower. That is because in these two countries working hours are lower in the public sector (in Italy also due to an underestimation of working hours in the public sector ${ }^{16}$ ) than in LPEs and in the private sector as a whole. In France there is no public wage gap at all, in Germany only with respect to the whole private sector and in the UK for females and/or private sector.

\section{Figure 3 - Average gross hourly earnings for full timers in the private sector (percentage ratio with respect to the corresponding value for public employees)}

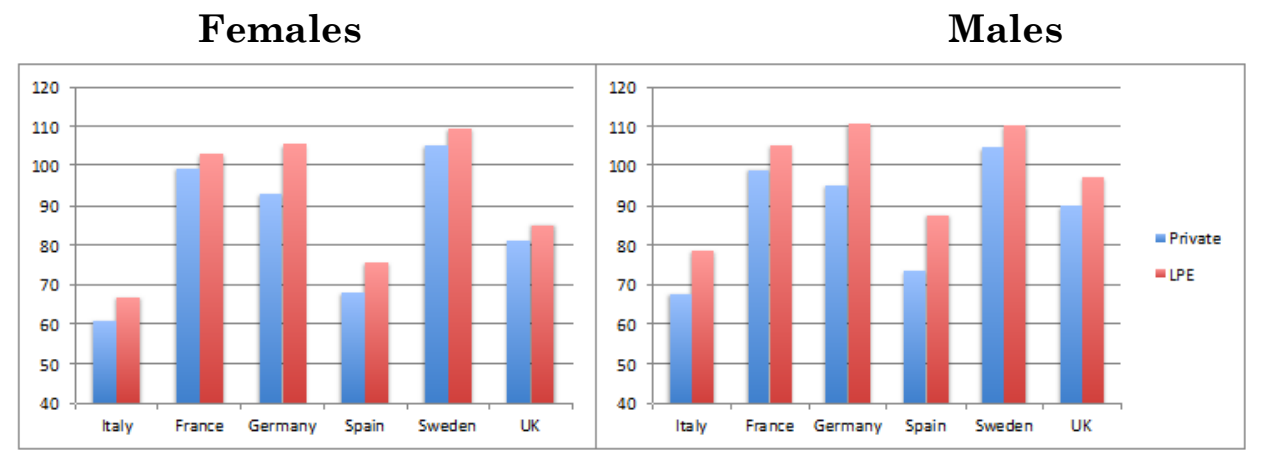

Source: Own elaboration on the Structure of Earning Survey, EUROSTAT, 2010

There are several factors (such as age, education and type of occupation) that can contribute to explain the observed wage gap at the aggregated level.

16 In Italy the SES data on earnings for public employees mostly come from administrative sources; these sources do not report information about the number of hours paid, so the database reports primarily contractual working hours that could underestimate significantly actual working hours, especially in Education sector. Moreover, note that SES does not report the data on hourly earnings for Italy and Sweden, so they are estimated as a ratio between monthly earnings and number of hours paid. As a consequence, the probable underestimation of the number of hours paid in Italy would imply an overestimation of hourly earnings for civil servants in this country. Matters are less clear a priori for Sweden. 
A first factor that can contribute to explain the differences between public sector and LPEs (and private sector) is the different age profile, with the employees' average age higher in the public sector and earnings increasing with age.

When we consider hourly earnings for females there is a consistent wage gap in favour of the public sector in Italy, Spain and the UK for all age group and in Germany for older employees. For males the gap is positive for public employees in Italy and Spain for all age groups and in the UK for the extreme age groups.

A second factor that could contribute to explain the public sector wage gap is the different level of education attained: in the public sector it is generally higher than in the whole private sector and in the LPEs. The analysis on hourly earnings shows that the public wage gap regards mostly employees with low level of education, prevalently females than males, especially in Italy, Spain and the UK (Figure 4).

Figure 4 - Average gross hourly earnings for full timers in LPEs, by level of education (percentage ratio with respect to the corresponding value for public employees)

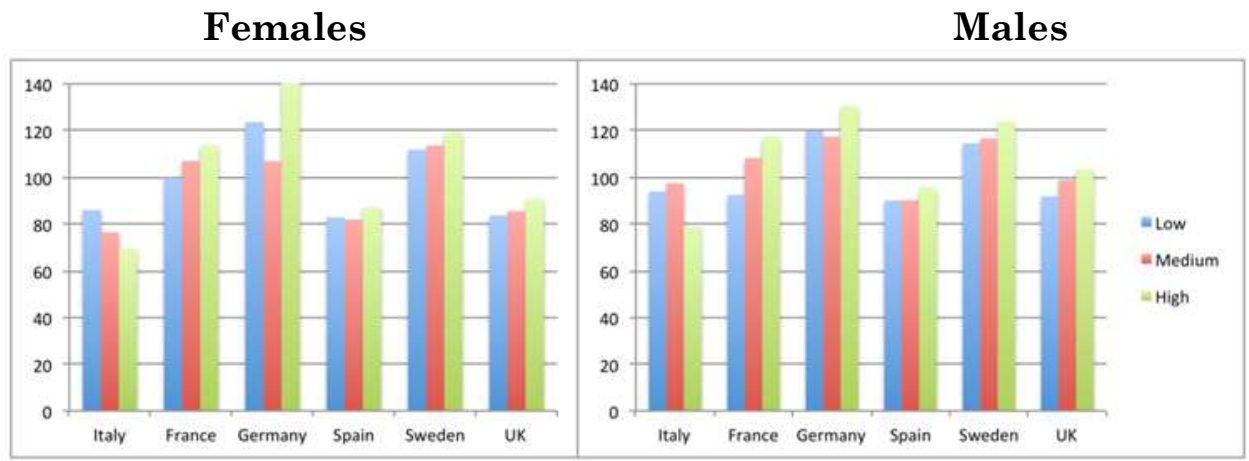

Source: Own elaboration on the Structure of Earning Survey, EUROSTAT, 2010

The picture changes when we consider monthly earnings. The changes involve mostly countries with recorded lower hours paid in the public sector than in LPEs. A significant public sector wage gap exists only for females in Spain and the UK and a very limited wage gap only for low educated females in Italy.

A third factor that can contribute to explain the wage gap is the difference in the jobs actually performed by employees in the public 
sector and in the LPEs. We have aggregated the different occupations in three categories: Managers, Professionals and Others ${ }^{17}$.

Looking at the type of occupation, we find a positive wage gap in favour of public sector for females for all types of occupations in Italy, the UK (very limited for Professionals) and Spain (very limited for Managers). In France there is a little advantage for public Managers. A positive wage gap for the male public employees exists in Italy and Spain, for Professionals and Others, in France and the UK, only for Others. When we consider the monthly earnings the picture changes a little. For females there is a public sector wage gap only in Spain for Professionals and Others, and in the UK for Managers and Others. There is also a limited wage gap in favour of public Managers in Italy.

Summing up, contrary to the results of the previous studies, the analysis based on raw data shows no clear evidences of a wage gap in favour of public employees. Public employees earn on average more than their colleagues active in the LPEs in the UK, Spain and in some cases in Italy. These results are in part different when we consider monthly instead of hourly earnings. The greater differences are recorded in Italy, but we have already stressed that these differences may depend on a biased estimation of working hours.

The magnitude of the wage gap is reduced or even vanishes when we consider that public employees present higher average job tenure, age, level of education and the number of managers and professionals is higher in the public sector as compared to LPEs.

Obviously, the gap is higher when we consider the private sector as whole instead of the LPEs.

\subsection{The Oaxaca-Blinder decomposition}

As already noted in Section 4, we resort to the Oaxaca-Blinder decomposition techniques in order to distinguish the effects of observable variables. In this paper we first present a detailed decomposition model for both whole private sector and LPEs (we present the decomposition only for the explained part as we have

17 This classification is based on the "Codes for occupation (ISCO-08)". In the group, defined as Managers, there are workers which occupation belongs to the Major Group 1 (Managers) of ISCO-08; in the second group, Professionals, the workers of the Major Group 2 (Professionals) and 3 (Technicians and associate Professionals); in the third group, Others, all other workers. 
noticed that the results for the unexplained part are ambiguous), then we carry on our analysis considering only two fold model limited to the LPEs. Although we believe that a correct analysis should be based on monthly earnings, we present our results based on hourly earnings ${ }^{18}$; then we comment which way the results differ once monthly earnings are used.

A list of explanatory variables is provided below (table 1).

Table 1. Description of explanatory variables.

\begin{tabular}{|c|c|}
\hline Variable & Label \\
\hline a12 & Size of the enterprise \\
\hline - a121 & less than 49 employees \\
\hline - a122 & 50-249 employees \\
\hline - a123 & more than 250 employees \\
\hline b21 & Gender \\
\hline - b121 & Male \\
\hline b22 & Age \\
\hline$-\mathrm{b} 221$ & 20-29 years \\
\hline$-b 222$ & 30-39 years \\
\hline$-b 223$ & 40-49 years \\
\hline - b224 & 50-59 years \\
\hline$-b 225$ & $60+$ years \\
\hline b23 & Type of occupation \\
\hline$-\mathrm{b} 231$ & Managers \\
\hline$-b 232$ & Professionals \\
\hline$-b 233$ & Others \\
\hline b25* & $\begin{array}{l}\text { Highest successfully completed level of education and } \\
\text { training }\end{array}$ \\
\hline$-b 251$ & ISCED 1 \\
\hline$-b 252$ & ISCED 2 \\
\hline$-b 253$ & ISCED 3 \\
\hline - b254 & ISCED 4 \\
\hline$-\mathrm{b} 255$ & ISCED 5 \\
\hline - b256 & ISCED 6 \\
\hline b26 & length of service in enterprise, in years (job tenure) \\
\hline b28** & Type of employment contract \\
\hline$-\mathrm{b} 281$ & Indefinite duration \\
\hline
\end{tabular}

18 An anonymous referee made a note that in many cases the results (based on monthly or hourly earnings) are very similar, suggesting us to limit the analysis to hourly earnings, also because they have been used more frequently in the existing literature. 


\begin{abstract}
- b282 Temporary/ fixed duration
- b283 Apprentice

* Germany provides a reduced classification for the level of education attained, limited to three groups.

** Not all countries present data on apprenticeship. Sweden does not provide data for the variable b28 at all.

Source: Own elaboration on the Structure of Earning Survey, EUROSTAT, 2010

Note that relying on the rich information of the SES dataset, we included among the explanatory variables such characteristics as firm size and job tenure, which are not very common for other datasets.

The analysis based on the hourly earnings shows the existence of a positive wage premium for the public employees with respect to private employees in Italy, Spain and the UK, for both females and males (Table 2). Generally females are comparatively better than males in the public sector than in the private. When we limit our analysis only to LPEs we obtain a reduction of the advantages for the public employees or an increase of the advantages for the private employees ${ }^{19}$. In Italy the advantage for males disappears and the one for females is very limited (0.033 log points or $3.4 \%)$.
\end{abstract}

19 If we compare monthly earnings of employees in the public sector with the ones of their colleagues in the whole private sector we obtain an increase of the advantages for the employees in the public sector or better a reduction of the advantages for private employees. In some cases the sign of the results changes: in Spain and the UK there is also a wage premium for males in the public sector, in Germany the advantage for females in LPEs disappears (only when the second model is considered). Only selected tables have been included in the paper; a complete set of tables can be provided upon request. 
Table 2. Oaxaca-Blinder decomposition (hourly earnings) ${ }^{20}$.

A) ITALY

\begin{tabular}{lccc|ccc}
\hline & Total & Males & Females & Total & Males & Females \\
\hline \multicolumn{3}{c}{ Private } & \multicolumn{3}{c}{ LPEs } \\
\hline Difference & $\mathbf{0 . 4 0 5}$ & $\mathbf{0 . 3 6 0}$ & $\mathbf{0 . 4 9 2}$ & $\mathbf{0 . 2 8 9}$ & $\mathbf{0 . 2 2 6}$ & $\mathbf{0 . 4 0 7}$ \\
Explained & $\mathbf{0 . 3 0 1}$ & $\mathbf{0 . 2 8 8}$ & $\mathbf{0 . 3 5 5}$ & $\mathbf{0 . 2 5 6}$ & $\mathbf{0 . 2 2 3}$ & $\mathbf{0 . 3 4 3}$ \\
- Gender & -0.030 & & & -0.026 & & \\
- Age & 0.048 & 0.045 & 0.055 & 0.051 & 0.048 & 0.057 \\
- Occupation & 0.108 & 0.070 & 0.141 & 0.094 & 0.046 & 0.147 \\
- Education & 0.120 & 0.118 & 0.101 & 0.101 & 0.098 & 0.090 \\
- Tenure & 0.053 & 0.051 & 0.056 & 0.033 & 0.025 & 0.049 \\
- Contract & 0.002 & 0.005 & 0.002 & 0.002 & 0.005 & $0.001^{*}$ \\
Unexplained & $\mathbf{0 . 1 0 4}$ & $\mathbf{0 . 0 7 2}$ & $\mathbf{0 . 1 3 7}$ & $\mathbf{0 . 0 3 3}$ & $\mathbf{0 . 0 0 3 *}$ & $\mathbf{0 . 0 6 4}$ \\
\hline
\end{tabular}

B) FRANCE

\begin{tabular}{lccc|ccc}
\hline & Total & Males & Females & Total & Males & Females \\
\hline \multicolumn{5}{c}{ Private } & \multicolumn{3}{c}{ LPEs } \\
\hline Difference & $\mathbf{0 . 0 1 0 *}$ & $\mathbf{0 . 0 4 2}$ & $\mathbf{0 . 0 1 9 * *}$ & $\mathbf{- 0 . 0 4 2}$ & $\mathbf{- 0 . 0 2 3 * *}$ & $\mathbf{- 0 . 0 1 5 *}$ \\
Explained & $\mathbf{0 . 0 4 5}$ & $\mathbf{0 . 0 6 9}$ & $\mathbf{0 . 0 6 5}$ & $\mathbf{0 . 0 0 9 *}$ & $\mathbf{0 . 0 2 0}$ & $\mathbf{0 . 0 4 6}$ \\
- Gender & -0.022 & & & -0.021 & & \\
- Age & 0.016 & 0.020 & 0.013 & 0.013 & 0.016 & 0.013 \\
- Occupation & $0.001 *$ & $-0.005^{*}$ & $0.009 * *$ & -0.017 & -0.028 & $-0.000^{*}$ \\
- Education & 0.029 & 0.024 & 0.027 & 0.020 & 0.013 & 0.023 \\
- Tenure & 0.029 & 0.032 & $0-027$ & 0.021 & 0.025 & 0.021 \\
- Contract & -0.008 & $-0.002 *$ & -0.010 & -0.009 & $-0.006 *$ & -0.010 \\
Unexplained & $\mathbf{- 0 . 0 3 5}$ & $\mathbf{- 0 . 0 2 8}$ & $\mathbf{- 0 . 0 4 6}$ & $\mathbf{- 0 . 0 5 1}$ & $\mathbf{- 0 . 0 4 3}$ & $\mathbf{- 0 . 0 6 2}$ \\
\hline
\end{tabular}

20 In our results we indicate with * Parameters for which the level of statistical significance is lower than 95\% $(\mathrm{P}(\mathrm{t})>0.05)$ and ** Parameters for which the level of significance ranges between $95 \%$ and $99 \%(0.01<\mathrm{P}(\mathrm{t})<0.05)$. 


\section{C) GERMANY}

\begin{tabular}{lccc|ccc}
\hline & Total & Males & Females & Total & Males & Females \\
\hline \multicolumn{3}{c|}{ Private } & \multicolumn{3}{c}{ LPEs } \\
\hline Difference & $\mathbf{0 . 0 4 9}$ & $\mathbf{0 . 0 8 2}$ & $\mathbf{0 . 0 9 8}$ & $\mathbf{- 0 . 1 1 6}$ & $\mathbf{- 0 . 0 9 1}$ & $\mathbf{- 0 . 0 4 3}$ \\
Explained & $\mathbf{0 . 1 0 5}$ & $\mathbf{0 . 1 6 5}$ & $\mathbf{0 . 1 0 5}$ & $\mathbf{0 . 0 2 2}$ & $\mathbf{0 . 0 7 2}$ & $\mathbf{0 . 0 5 2}$ \\
- Gender & -0.026 & & & -0.028 & & \\
- Age & -0.004 & $-0.000 *$ & -0.002 & -0.006 & -0.002 & -0.004 \\
- Occupation & 0.067 & 0.076 & 0.047 & 0.041 & 0.043 & 0.032 \\
- Education & 0.082 & 0.071 & 0.094 & 0.069 & 0.057 & 0.086 \\
- Tenure & 0.050 & 0.055 & 0.048 & 0.016 & 0.017 & 0.021 \\
- Contract & -0.065 & -0.037 & -0.082 & -0.069 & -0.043 & -0.083 \\
Unexplained & $\mathbf{- 0 . 0 5 5}$ & $\mathbf{- 0 . 0 8 2}$ & $\mathbf{- 0 . 0 0 7}$ & $\mathbf{- 0 . 1 3 9}$ & $\mathbf{- 0 . 1 6 3}$ & $\mathbf{- 0 . 0 9 5}$ \\
\hline
\end{tabular}

\section{D) SPAIN}

\begin{tabular}{|c|c|c|c|c|c|c|}
\hline & Total & Males & Females & Total & Males & Females \\
\hline & \multicolumn{3}{|c|}{ Private } & \multicolumn{3}{|c|}{ LPEs } \\
\hline Difference & 0.344 & 0.330 & 0.405 & 0.197 & 0.143 & 0.304 \\
\hline Explained & 0.164 & 0.178 & 0.197 & 0.107 & 0.083 & 0.187 \\
\hline - Gender & -0.030 & & & -0.024 & & \\
\hline - Age & 0.016 & 0.016 & 0.016 & 0.013 & 0.011 & 0.019 \\
\hline - Occupation & 0.047 & 0.034 & 0.058 & 0.033 & 0.013 & 0.057 \\
\hline - Education & 0.067 & 0.060 & 0.059 & 0.052 & 0.030 & 0.070 \\
\hline - Tenure & 0.068 & 0.070 & 0.069 & 0.040 & 0.036 & 0.047 \\
\hline - Contract & -0.004 & -0.002 & -0.005 & -0.008 & -0.007 & -0.006 \\
\hline Unexplained & 0.180 & 0.152 & 0.208 & 0.090 & 0.061 & 0.118 \\
\hline
\end{tabular}


E) SWEDEN

\begin{tabular}{|c|c|c|c|c|c|c|}
\hline & Total & Males & Females & Total & Males & Females \\
\hline & \multicolumn{3}{|c|}{ Private } & \multicolumn{3}{|c|}{ LPEs } \\
\hline Difference & -0.065 & -0.035 & -0.029 & -0.108 & -0.083 & -0.064 \\
\hline Explained & 0.082 & 0.128 & 0.105 & 0.068 & 0.107 & 0.096 \\
\hline - Gender & -0.037 & & & -0.035 & & \\
\hline - Age & 0.025 & 0.021 & 0.030 & 0.023 & 0.019 & 0.028 \\
\hline - Occupation & 0.035 & 0.043 & 0.026 & 0.025 & 0.032 & 0.020 \\
\hline - Education & 0.049 & 0.057 & 0.038 & 0.048 & 0.051 & 0.041 \\
\hline - Tenure & 0.010 & 0.007 & 0.011 & 0.007 & 0.005 & 0.007 \\
\hline Unexplained & -0.147 & -0.163 & -0.133 & -0.175 & -0.189 & -0.159 \\
\hline
\end{tabular}

F) UNITED KINGDOM

\begin{tabular}{|c|c|c|c|c|c|c|}
\hline & Total & Males & Females & Total & Males & Females \\
\hline & \multicolumn{3}{|c|}{ Private } & \multicolumn{3}{|c|}{ LPEs } \\
\hline Difference & 0.177 & 0.182 & 0.266 & 0.122 & 0.119 & 0.229 \\
\hline Explained & 0.049 & 0.078 & 0.106 & 0.049 & 0.076 & 0.111 \\
\hline - Gender & -0.041 & & & -0.041 & & \\
\hline - Age & 0.023 & 0.027 & 0.020 & 0.022 & 0.027 & 0.019 \\
\hline - Occupation & 0.047 & 0.031 & 0.067 & 0.045 & 0.026 & 0.069 \\
\hline - Education & 0.021 & 0.021 & 0.018 & 0.022 & 0.021 & 0.020 \\
\hline - Tenure & 0.001 & 0.001 & 0.001 & 0.003 & 0.003 & 0.004 \\
\hline - Contract & -0.002 & -0.002 & -0.001 & -0.001 & $-0.001^{* *}$ & -0.001 \\
\hline Unexplained & 0.127 & 0.104 & 0.160 & 0.073 & 0.043 & 0.118 \\
\hline
\end{tabular}

Source: Own elaboration on the Structure of Earning Survey, EUROSTAT, 2010

If we consider the monthly earnings instead of the hourly earnings we obtain a different picture: only in Spain and the UK we have a reduced public sector wage premium with respect to the whole private sector; and only a slight wage premium remains for females in Spain and the UK, respectively about 5\% and 8\%, with respect to their colleagues in LPEs.

Generally we observe that a large part of the differences between earnings gained in the public and in the private sector are explained by the variables used in our estimations. The major contributions to the explanation are provided by the level of education attained: since the 
public sector employs workers with a higher average level of education we observe apparent gap between earnings that can be explained by differences in skills. Other variables that contribute significantly to explain the observed differences are occupation and tenure; both these variables present higher values in the public sector.

Summing up, the results of Oaxaca-Blinder decomposition show the existence of a public sector wage premium in Spain and the UK, both for monthly and hourly earnings, and in Italy only for hourly earnings. In other countries a negative premium always shows up for civil servants.

One of the main limits of Oaxaca-Blinder decomposition model is that its results represent only mean values that could not be representative for all employees, which may be also the outcome of variable omission. Indeed, some groups of workers could obtain economic advantages in working in the public sector. By looking at the aggregate values we are not able to appreciate this. There are several ways to deal with heterogeneity, in this paper we present a method based on the disaggregation by subgroups, limited to the comparison with LPEs.

In our analysis we consider three distinct groups of educational attainment, in order to simplify our analysis and to make international comparisons possible ${ }^{21}$.

The results basically show that the level of educational attainment has a systematic impact on the wage premium. Generally, in line with most of the available evidence, less educated employees are relatively better off in the public sector than in LPEs.

With hourly earnings we find a wage premium for males and females in Spain and in the UK, particularly high for females (in both countries the premium is about 15\%), for females in Italy (less than 10\%) and for males in France (about 6\%). The premium is lower when we use monthly earnings: it disappears in Italy and for males in Spain and the UK.

For employees with medium level of education a significant and consistent public sector wage premium there is found in Spain and the UK, for both males and females (although slightly lower than in the case for low level of education); a limited public sector wage premium exists also for females in Italy (0.039 log points or 4.0\%). With monthly earnings a public sector wage premium exists only for females in Spain and the UK, respectively $0.072 \log$ points or $7.5 \%$ and $0.094 \log$ points

${ }^{21}$ See note 14 . 
or $9.9 \%$. In all other countries there is a significant wage premium for employees in LPEs, even for females.

Finally, when we consider the employees with high level of education, we also obtain a different picture depending on the use of monthly or hourly earnings. With monthly earnings we observe that a public sector wage premium exists only for females in the UK, however of lower magnitude (0.047 log points or 4.8\%). The value of wage premium for employees in LPEs is particularly high in Sweden and France, especially for males (about -0.250 log points or $-22.1 \%$ ).

When we consider hourly earnings we can see that a public wage premium exists also for females in Italy (and also significant, $0.107 \mathrm{log}$ points or $11.3 \%)$, in the UK (0.091 log points or 9.5\%) and in Spain (more limited than Italy and the UK, $0.056 \mathrm{log}$ points or 5.8\%). A limited wage premium is also found in the UK for male employees in the public sector (0.032 log points or 3.3\%).

On the whole, the public sector wage premium and its magnitude seem to be more sizeable for females than males, for loweducated employees than high-educated employees and when we consider hourly earnings instead of monthly earnings. Finally we have to stress that the evidence is more favourable to the existence of a public sector wage gap when we compare earnings in the latter with those of the whole private sector. This is consistent with a stronger role played in wage determination by trade unions in the public sector and in LPEs.

As already mentioned, we have another way to deal with heterogeneity or to face the criticism that the comparison of all public workers with all private workers does not make sense since some works can exist only in the public sector and other works cannot exist there. We carry out the public-private comparison only within sectors in which there are both public and private employers. To this end we could consider Education, Health and Local utilities sectors defined in Section 3 .

However for the Education sector we have problems to carry out a correct analysis for two order of reasons: 1) as previously observed (see for example Giordano et. al., 2011) there are problems of measurement for hourly earnings in Education, especially in Italy; 2) in many countries the size of the private local units active in this sector is very low, so they are out of reach of the analysis since data on enterprises with less than 10 employees is available only for few countries on a voluntary basis. Knowing these caveats is important for 
a correct interpretation of our results and we think it is important to keep track of them.

For the Education sector we observe a very different situation with respect to the picture obtained from the aggregated data (Table 3).

Table 3. Oaxaca-Blinder decomposition for Education (hourly earnings).

\begin{tabular}{|c|c|c|c|c|c|c|}
\hline & Total & Males & Females & Total & Males & Females \\
\hline & \multicolumn{3}{|c|}{ ITALY } & \multicolumn{3}{|c|}{ FRANCE } \\
\hline Difference & 0.689 & 0.406 & 0.783 & $0.076^{*}$ & $-0.126^{*}$ & 0.246 \\
\hline Explained & 0.436 & 0.232 & 0.483 & 0.151 & 0.132 & 0.185 \\
\hline \multirow[t]{2}{*}{ Unexplained } & 0.252 & $0.174 *$ & 0.300 & $-0.075^{*}$ & $-0.258 * *$ & $0.060 *$ \\
\hline & \multicolumn{3}{|c|}{ GERMANY } & \multicolumn{3}{|c|}{ SPAIN } \\
\hline Difference & 0.818 & 1065 & 0.587 & $-0.079 * *$ & $-0.048^{*}$ & $-0.098 * *$ \\
\hline Explained & 0.597 & 0.928 & 0.345 & $-0.050 * *$ & $-0.002^{*}$ & -0.076 \\
\hline \multirow[t]{2}{*}{ Unexplained } & 0.220 & 0.137 & 0.242 & $-0.029 *$ & $-0.046 *$ & $-0.022 *$ \\
\hline & \multicolumn{3}{|c|}{ SWEDEN } & \multicolumn{3}{|c|}{ UK } \\
\hline Difference & 0.074 & 0.072 & 0.078 & $-0.013^{*}$ & $-0.012^{*}$ & $0.001^{*}$ \\
\hline Explained & 0.096 & 0.103 & 0.088 & -0.045 & $-0.029 *$ & $-0.042^{* *}$ \\
\hline Unexplained & -0.022 & $-0.031^{* *}$ & $-0.010 *$ & $0.032 *$ & $0.017 *$ & $0.042 *$ \\
\hline
\end{tabular}

The most important difference regards Germany where we now witness very high values for the public sector wage premium. In this country the wage gap seems very high: males working into the public sector earn three times the colleagues in the LPEs (1.065 log points represents a gap of $190.1 \%)$. When we consider the unexplained part the differences are reduced but always consistent $(0.137$ log points or $14.7 \%)$.

Other important differences with the aggregate estimates are represented by the absence of a wage premium for public employees in Spain and the UK and for employees in LPEs in Sweden. In Spain a limited wage premium exists for females (about 5\%) when we consider monthly earnings instead of hourly earnings; in Italy there is a positive wage premium for male employees in the public sector with hourly earnings and a negative one with monthly earnings. In both cases they are not statistically significant, although not negligible. 
Also for Health sector we register some significant differences vis-à-vis the aggregate estimates. In Italy, Spain and the UK we see a significant wage premium for public employees, both males and females. Also in Germany there is a public sector wage premium, but this premium is much smaller than in the previous three countries (Table 4).

Table 4. Oaxaca-Blinder decomposition for Health (hourly earnings).

\begin{tabular}{lccc|ccc}
\hline & Total & Males & Females & Total & Males & Females \\
\hline \multicolumn{3}{c}{ ITALY } & \multicolumn{3}{c}{ FRANCE } \\
\hline Difference & 0.526 & 0.460 & 0.497 & $-0.001^{*}$ & $0.115^{* *}$ & $-0.040^{*}$ \\
Explained & 0.236 & 0.201 & 0.184 & $0.011^{*}$ & $0.078^{* *}$ & $-0.011^{*}$ \\
Unexplained & $\mathbf{0 . 2 8 9}$ & $\mathbf{0 . 2 5 9}$ & $\mathbf{0 . 3 1 2}$ & $\mathbf{- 0 . 0 1 2 *}$ & $\mathbf{0 . 0 3 7 *}$ & $\mathbf{- 0 . 0 3 7 * *}$ \\
\hline \multicolumn{3}{c}{ GERMANY } & \multicolumn{3}{c}{ SPAIN } \\
\hline Difference & 0.062 & 0.068 & 0.068 & 0.465 & 0.504 & 0.446 \\
Explained & 0.025 & $0.035^{* *}$ & 0.029 & 0.210 & 0.248 & 0.188 \\
Unexplained & $\mathbf{0 . 0 3 7}$ & $\mathbf{0 . 0 3 3}$ & $\mathbf{0 . 0 4 0}$ & $\mathbf{0 . 2 5 5}$ & $\mathbf{0 . 2 5 6}$ & $\mathbf{0 . 2 5 9}$ \\
\hline & \multicolumn{3}{c|}{ SWEDEN } & & UK & \\
\hline Difference & 0.090 & 0.127 & 0.075 & 0.521 & 0.617 & 0.472 \\
Explained & 0.163 & 0.246 & 0.129 & 0.226 & 0.308 & 0.183 \\
Unexplained & $\mathbf{- 0 . 0 7 3}$ & $\mathbf{- 0 . 1 1 9}$ & $\mathbf{- 0 . 0 5 4}$ & $\mathbf{0 . 2 9 5}$ & $\mathbf{0 . 3 0 9}$ & $\mathbf{0 . 2 8 9}$ \\
\hline Own elaboration on the Structure of Earning Survey EUROSTAT 2010
\end{tabular}

To better understand these results we must remember that Health sector includes also social care activities or social services, generally performed by private (for-profit or non-profit institutions), often characterised by a high presence of females, low paid jobs and high turnover (Eurofound, 2006). To investigate these problems we need more specific analysis that is out of the scope of this work.

For Local utilities we observe the presence of a general although not very large - public sector wage premium in quite all countries, with the only exception represented by Germany. In some cases (Italy and females in France and the UK) the value for the premium is not statistically significant (Table 5). The highest value is the premium for males in Spain: 0.158 log points or 17.1\%. Another 
interesting feature of these results is that, unlike in the rest of the estimates, female workers fare worse than their male colleagues.

\section{Table 5. Oaxaca-Blinder decomposition for Local utilities} (hourly earnings).

\begin{tabular}{lccc|ccc}
\hline & Total & Males & Females & Total & Males & Females \\
\hline \multicolumn{3}{c}{ ITALY } & \multicolumn{3}{c}{ FRANCE } \\
\hline Difference & 0.053 & 0.044 & $0.081^{* *}$ & 0.167 & 0.182 & 0.089 \\
Explained & 0.036 & 0.026 & 0.065 & 0.087 & 0.091 & $0.061^{* *}$ \\
Unexplained & $\mathbf{0 . 0 1 8 ^ { * }}$ & $\mathbf{0 . 0 1 9 *}$ & $\mathbf{0 . 0 1 6 *}$ & $\mathbf{0 . 0 7 9}$ & $\mathbf{0 . 0 9 1}$ & $\mathbf{0 . 0 2 8 *}$ \\
\hline \multicolumn{3}{c}{ GERMANY } & \multicolumn{3}{c}{ SPAIN } \\
\hline Difference & 0.015 & $0.003^{*}$ & 0.040 & 0.243 & 0.229 & 0.231 \\
Explained & 0.023 & $0.007^{*}$ & 0.054 & 0.096 & 0.071 & 0.114 \\
Unexplained & $\mathbf{- 0 . 0 0 7 * *}$ & $\mathbf{- 0 . 0 0 4 *}$ & $\mathbf{- 0 . 0 1 4 *}$ & $\mathbf{0 . 1 4 7}$ & $\mathbf{0 . 1 5 8}$ & $\mathbf{0 . 1 1 7}$ \\
\hline \multicolumn{3}{c}{ SWEDEN } & \multicolumn{4}{c}{ UK } \\
\hline Difference & 0.107 & 0.129 & 0.049 & 0.170 & 0.159 & 0.225 \\
Explained & 0.065 & 0.081 & 0.035 & 0.042 & $0.026^{*}$ & 0.109 \\
Unexplained & $\mathbf{0 . 0 4 2}$ & $\mathbf{0 . 0 4 8}$ & $\mathbf{0 . 0 1 4}$ & $\mathbf{0 . 1 2 8}$ & $\mathbf{0 . 1 3 2}$ & $\mathbf{0 . 1 1 5 * *}$ \\
\hline Source: Own elaboration on the Structure of Earning Survey, EUROSTAT, 2010
\end{tabular}

Summing up, we have observed some differences between the aggregate estimates and the estimates by sector for three fundamental fields of public intervention, namely Education, Health and Local utilities. Looking at Education we do not observe very significant differences between public sector and LPEs in Spain, Sweden and the UK. The most striking results show up for Germany: contrary to what found at the aggregate level, there is a wage premium for civil servants. In France and Italy the results are more ambiguous and not always statistically significant. In Health, with the exception of Sweden and perhaps France, we observe a positive and high wage premium for public employees. In several cases this premium results to be particularly high, like in Italy and Spain. In Local utilities we observe also a positive wage premium for public employees, but in this case it is not very high (except for Spain and the UK when we consider hourly earnings).

Therefore, these data yield a different picture than the one emerging from the analysis on the whole economy. The low significance 
of the estimated coefficients pervades the comparison between public sector and LPEs within sectors of economic activities, especially for Education. This problem could derive from the reduced number of LPEs in some sectors.

\section{Concluding remarks}

In this paper we have presented some relatively novel evidence on the public-private wage gaps for six European countries, using a database until now not widely used, the Eurostat Structure of Earnings Survey.

The results show the existence of a public sector wage premium in Spain and the UK, both for monthly and hourly earnings, and in Italy only for hourly earnings, probably also due to an overestimation of hourly earnings for public employees in Education, sector accounting for about half of total civil servants in Italy. However, this result is consistent with the literature on the public-private differentials that has shown higher public wage premia when they are calculated on hourly earnings instead of monthly earnings (see, for example, Giordano et al., 2011; Christofides and Michael, 2013).

In the other countries a negative premium always shows up for civil servants. In all of the countries considered there are not very large differences when we compare the public sector to private sector instead of LPEs. When examining gender differences in monthly earnings, the wage gap is consistent in Germany (where the negative gap is larger in absolute terms - for males), and in Spain and the UK, where the gap favours more heavily female public employees more than their male counterparts. Nothing much shows up in Italy, France and Sweden. In hourly earnings the wage gap in favour of female civil servants is larger in Italy, Spain, and UK. Public sector females also enjoy a better situation than their male colleagues in Germany and Sweden (although the wage gap is negative there), while in France gender differences are very low. Country-wise, our results are broadly consistent with those (also relying on the SES) of Ramos et al. (2014) for Spain, and of de Castro et al. (2013), analysed in section 2 (literature survey).

Some differences emerging vis-à-vis the latter study (mainly for Germany and the UK) must be ascribed, in our opinion, to the fact that their raw wage gaps are measured from samples including part-timers. 
Our findings might differ from previous results due to the following reasons:

1) recent data (up to 2010) from a single source (EU-SES) are used. It is worthwhile pointing out that the great majority of previous cross-country analyses about the public sector used either national (un-harmonised) data-sets or the EU-SILC, which does not have explicit info about the public sector, does not have info on job tenure, and has considerably less observations than the SES;

2) the public-private comparison poises the determination of earnings for workers in the public sector with respect to their appropriate counterparts working at LPEs. Indeed, the rules governing the labour market in the public sector are more homogeneous than those of the private sector. Trade-union strength and human resource management tend to be more similar in the public sector and in LPEs. The use of the SES allows this comparison when assessing the determination of the public wage premium

We carry our estimates on restricted samples: worker groups characterised by similar educational attainment, and belonging to the same sectors (Education, Human health and social work activities, and local utilities). Some jobs exist only in the public sector; for these jobs (in public administration and defence; compulsory social security) the comparison between public and private sector does not make sense ${ }^{22}$. Once more, the information provided by SES is crucial for this kind of analysis.

When we consider wage gaps by sub-groups with different levels of educational attainment, the picture is consistent with the one obtained from the aggregate data. In Germany, Sweden and to a large extent in France there are no public sector wage premia by level of educational attainment, both for males and females. However, also in these countries, the wage premium for LPEs is positively correlated with the level of educational attainment. Less-educated civil servants are always, in a sense, better off. This is true also in those countries where there is a public sector wage premium for some levels of

\footnotetext{
22 As already observed in the literature survey, people can prefer to work in the public sector also in absence of a wage premium. The reason is the different degree of risk aversion between public and private employees (see for example Bellante and Link, 1981, and Gregory and Borland, 1999).
} 
education, in particular when we consider hourly earnings (for the UK, Spain and Italy). The evidence is more favourable to the existence of a public sector wage gap when we compare earnings in the latter with those of the whole private sector. This is consistent with a stronger role played in wage determination by trade unions in the public sector and in LPEs.

We observe, on the other hand, some differences between the aggregate estimates and the estimates by sector for three fundamental fields of public intervention, including Education, Health, and Local utilities. Looking at Education we do not observe very significant differences between public sector and LPEs in Spain, Sweden and the UK. The most striking results show up for Germany: contrary to what is found at the aggregate level, there is a wage premium for civil servants. In France and Italy the results are more ambiguous and not always statistically significant. In Health, with the exception of Sweden and France, we observe a positive and high wage premium for public employees. In several cases this premium results particularly high (Italy and Spain). An interesting feature of the results for Local utilities (where we generally observe a small public wage premium) is that female civil servants fare worse than their male colleagues therein.

On the whole, the public sector wage premium seems to be more sizeable for females than males, for less-educated employees than highly-educated employees and when we consider hourly earnings instead of monthly earnings. Country-wise, our results are largely consistent with those of some previous studies relying on the SES. When focusing on estimates by sector, we find that a public sector wage premium emerges more frequently, with fairly high values for Health in Italy and Spain. All this evidence is broadly consistent with a strong role played by trade unions in the determination of public sector pay level. Also recall that, according to competitive models of pay determination, we should observe pervasively higher remuneration in the private sector if the public employment acts as a sort of welfare support provider, which is not what we found in this study. 


\section{References}

Alesina A., Danninger S., Rostagno M.V. (1999), Redistribution through Public Employment: The Case of Italy, NBER Working Paper Series, n. 7387.

Algan Y., Cahuc P., Zylberberg A. (2002), Public Employment and Labor Market Performances, Economic Policy, 17, 1-65.

Bargain O., Melly B. (2007), Public sector pay gap in France: new evidence using panel data, IZA Discussion Papers n. 3427.

Bellante D., Link A.N. (1981), Are public sector workers more risk averse than private sector workers?, Industrial and Labor Relations Review, 34 (3), 408-412.

Blinder A.S. (1973), Wage Discrimination: Reduced Form and Structural Estimates, Journal of Human Resources, 8 (4), 436-455.

Bonin H., Dohmen T., Falk A., Huffman D., Sunde U. (2007), Cross-sectional earnings risk and occupational sorting: The role of risk attitudes, Labour Economics, 6 (14), 926937.

Budria S. (2010), Schooling and the distribution of wages in the European private and public sectors, Applied Economics, 42 (8), 1045-1054.

Buurman M., Delfgaauw J., Dur R. Van den Bossche S. (2012), Public sector employees: Risk averse and altruistic?, Journal of Economic Behavior \& Organization, 83 (3), 279291.

Campos M.M., Depalo D., Papapetrou E., Perez J.J., Ramos R. (2016), Understanding the public sector pay gap, Banco de Portugal, Working Papers n. 6.

Cappellari L. (2002), Earnings dynamics and uncertainty in Italy: how do they differ between the private and public sectors?, Labour Economics, 9, 477-496.

Christofides L.N., Michael M. (2013), Exploring the public-private sector wage gap in European countries, IZA, Journal of European Labour Studies, 2-15.

Daymont T.N., Andrisani P. J. (1984), Job preferences, college major, and the gender gap in earnings, Journal of Human Resources, 19 (3), 408-428.

De Castro F., Salto M., Steiner H. (2013), The gap between public and private wages: new evidence for the EU, European Economy, Economic Papers, n. 508.

Dell'Aringa C., Lucifora C., Origo L. (2007), Public Sector Pay and Regional Competitiveness. A First Look at Regional Public-Private Wage Differentials in Italy, The Manchester School, 75 (4), 445-478.

Depalo D., Giordano R., Papapetrou E. (2013), Public-private wage differentials in euro area countries: evidence from quantile decomposition analysis, Banca d'Italia, Temi di Discussione, n. 907.

Depalo D., Giordano R. (2011), The public-private pay gap: a robust quantile approach, Banca d'Italia, Temi di Discussione, n. 824.

Disney R. (2007), Public-private sector wage differentials around the world: methods and evidence, mimeo, University of Nottingham. 
Eurofound - European Foundation for the Improvement of Living and Working Conditions (2006), Employment in Social Care in Europe.

Eurostat (2010), Structure of Earnings Survey 2010. Eurostat's arrangements for implementing the Council Regulation 530/1999, the Commission Regulations 1916/2000 and $1738 / 2005$.

Forni L., Giordano R. (2003), Employment in the public sector, CESifo Working Paper n. 1085 .

Fortin N., Lemieux T., Firpo S. (2010), Decomposition Methods in Economics, NBER Working Papers Series n. 16045.

Francois P. (2000), "Public service motivation" as an argument for government provision, Journal of Public Economics, 78, 275-299.

Gardeazabal, J., and A. Ugidos. (2004), "More on identification in detailed wage decompositions", Review of Economics and Statistics, 86 (4), 1034-1036.

Ghinetti P., Lucifora, (2013), Public/private wage gaps and skill levels: evidence from French, British and Italian micro data, International Journal of Manpower, 34 (5), 429446.

Giordano R., Depalo D., Coutinho Pereira M., Eugène B., Papapetrou E., Perez J.J., Reiss L., Roter M. (2011), The Public Sector Pay Gap in a Selection of Euro Area Countries, European Central Bank Working Papers Series n. 1406.

Gomes P. (2010), Fiscal policy and the labour market: The effect of public sector employment and wages, IZA, Discussion Paper n. 5321.

Gomes P. (2015), Optimal Public Sector Wages, The Economic Journal, 125 (587), 14251451.

Heckman J. (1979), Selection Bias as a Specification Error, Econometrica, 47 (1), 153162.

Hospido L., Moral-Benito E. (2014), The public sector wage premium in Spain: evidence from longitudinal administrative data, Banco de Espãna, Documentos de Trabajo n. 1422 .

Istat (2010), Struttura delle retribuzioni - Anno 2006. Nota Metodologica, mimeo.

Istat (2013), Struttura delle retribuzioni - Anno 2010. Nota Metodologica, mimeo.

Lucifora C., Meurs D. (2006), The Public Sector Pay Gap in France, Great Britain and Italy, The Review of Income and Wealth, 52 (1), 43-59.

Nopo, H. (2008), Matching as a Tool to Decompose Wage Gaps, The Review of Economics and Statistics, 90 (2), 290-299.

Oaxaca R.L. (1973), Male-female wage differentials in urban labour markets, International Economic Review, 14 (3), 693-709.

Pfeifer C. (2011), Risk aversion and sorting into public sector employment, German Economic Review, 12 (1), 85-99.

Postel-Vinay F., Turon H. (2007), The Public Pay Gap in Britain: Small Differences That (Don't) Matter, The Economic Journal, 117 (523), 1460-1503. 
Ramos R., Sanromá E., Simón H. (2014), Public-Private Sector Wage Differentials by Type of Contract: Evidence from Spain, IZA DP n. 8158.

Robinson J.A., Verdier T. (2013), The Political Economy of Clientelism, The Scandinavian Journal of Economy, 115(2), 260-291.

Vaughan-Whitehead D. (2013), Public Sector Shock. The Impact of Policy Retrenchment in Europe, ILO/Edward Elgar.

Winsborough H.H., Dickenson P. (1971), Components of negro-white income differences, Proceedings of the Social Statistics Section, 6-8. Washington DC, American Statistical Association.

Yun, M.S. (2005), "A simple solution to the identification problem in detailed wage decompositions", Economic Inquiry, 43 (4), 766-772. 